\title{
NEW HOST, GEOGRAPHICAL RECORD AND A SYNONYM FOR PHYLLODISTOMUM SPATULA ODHNER, 1902 (TREMATODA, GORGODERIDAE)
}

\author{
BERENICE M.M. FERNANDES
}

In the present note Phyliodistomum spatula Odhner, 1902 is recorded for the first time from Brazil and in a new host Colossoma macropomum (Cuvier, 1818) (Pisces, serrasalmidae), and Phyllodistomum spatulaeforme Odhner, 1902 is considered its synonym.

Examining one specimen of Colossoma macropomum from Ceará State, Brazil, we recovered from the body cavity, four specimens of $P$. spatula. These specimens are smaller than those already referred and a brief description and figures are presented, registering this species for the first time in Brazil and in a new host.

The trematodes were stained in alcoholic-acid carmine, dehydrated in EtOH, cleared in Faia's creosote and mounted in Canada balsam. The illustration was made with the aid of a drawing tube.

Description (based on four specimens; measurements in millimeters): Body spatulate 1.64-2.56 long by 1.02-1.29 wide. Forebody narrow, elongated and hindbody foliate, with more or less crenulated margin. Tegument smooth. Oral sucker terminal $0.15-0.35$ long by 0.14-0.27 wide. Acetabulum immediately pre-equatorial 0.19-0.24 long by 0.19. 0.27 wide. Sucker ratio 1:08-1:1.3. Pharynx absent. Esophagus $0.10-0.37$ long. Caeca terminating near posterior extremity. Testes intercaecal, entire or lobated, symmetrical or slightly oblique, 0.22-0.61 long by $0.19-0.34$ wide. No cirrus pouch. Seminal vesicle saccular, free in parenchyma, between acetabulum and esophageal bifurcation with 0.09 0.13 long by $0.05-0.13$ wide. Ovary submedian, pre-testicular, oval with irregular outline or lobated, 0.10-0.16 long by 0.13-0.19 wide. Seminal receptacle absent. Mehlis' gland and Laurer's canal not evidenciated. Vitellaria consisting of two compact glands in front of testes. Genital pore median, postbifurcal. Uterus occupying most of hindbody with inter and extracaecal loops. Eggs not operculated $0.026-0.030$ long by $0.016-0.021$ wide. Excretory vesicle tubular. Excretory pore terminal.

Host : Colossoma macropomum (Cuvier, 1818)

Site of infection: body cavity

Locality: Ceará State, Brazil

Specimens deposited in the Helminthological Collection of the Oswaldo Cruz Institute n? 31.931 a-d.

\section{DISCUSSION}

In 1902 Odhner describes from Africa Phyllodistomum spatula from urinary bladder of Bagrus bayad and B. docmac, and Phyllodistomum spatulaeforme from urinary bladder of Malapterurus eletricus, with brief descriptions. In 1911, the same author redescribes and illustrates these species in the genus Catoptroides Odhner, 1902. Lewis

Instituto Oswaldo Cruz. Departamento de Helmintologia, Caixa Postal 926, 20000 Rio de Janeiro, RJ, Brazil. Research Fellow, CNPq.

Received for publication October 20th and accepted December 28th, 1983. 


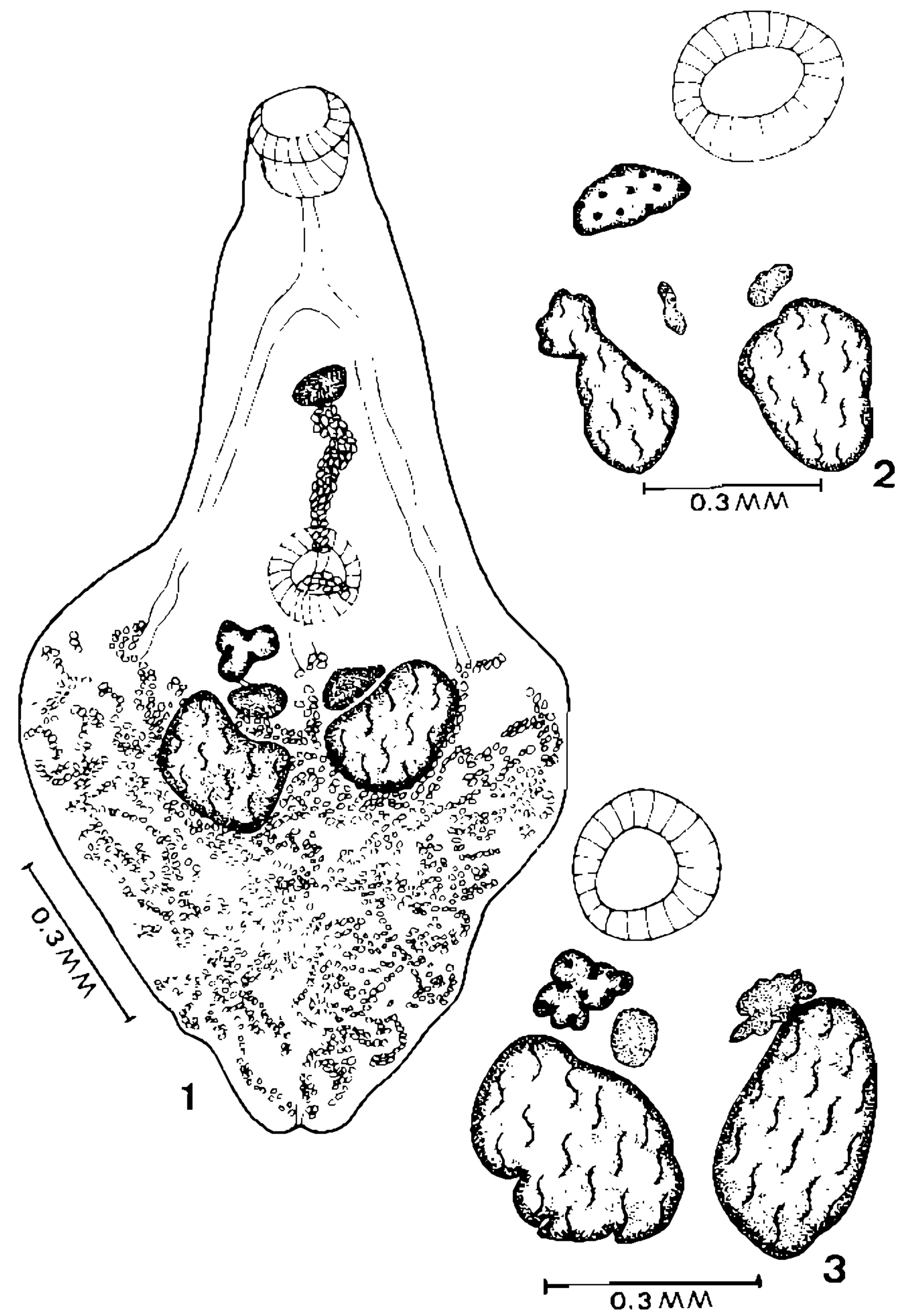

Phyllodistomum sparula Odhner, 1902. Original figures, ventral view. Fig. 1 - Total, 1.O.C. Helm. Coll. no 31.931c. Fig. 2 - Genital complex, showing ovary with irregular outline and testes slightly lobated, I.O.C. Helm. Coll. no 31.931b. Fig. 3 - Genital complex, showing ovary lobated and testes slightly lobated, I. O.C. Helm. Coll. nọ 31.931 a.

(1935) in his paper "The trematode genus Phyllodistomum Braun" separates $P$. spatula from $P$. spatulaeforme by the form and dimension of testes. Two years latter Bhalerao (1937) differentiates $P$. spatula from $P$. spatulaeforme considering the form of ovary (lobated or not), and position of testes (symmetrical or slightly oblique). Kakaji (1969) redescribes $P$. spatulaeforme collected from urinary bladder of Amphipnous cuchia from India, referring specimens with testes lobated or entire and considers $P$. chauhani Motwani \& Srivastava, 1961, $P$. ghanenses Thomas, 1958 and $P$. indianun Jaiswal, 1957 as synonyms of $P$. spatulaeforme. Gupta \& Verma (1977) describe $P$. spatulaeforme recovered from Ophicephalus punctatus, also from India, referring that their specimens differs in having ventral sucker smaller or larger than oral sucker instead of intercaecal or extracaecal and in the relative size of various organs. These authors consider these differences as individual variations.

As seen in our material, the characteristics used by Lewis (1935) (form and size of testes), and by Bhalerao (1937) (position of testes and ovary shape), to separate this 
two species, represents individual variations, and so, $P$. spatulaeforme may be regarded identical to $P$. spatula.

\section{RESUMO}

Na presente nota Phyllodistomum spatula Odhner, 1902 é assinalada pela primeira vez no Brasil, e em novo hospedeiro Colossoma macropomum (Cuvier, 1818); e Phyllodistomum spatulaeforme Odhner, 1902, considerado seu sinônimo.

\section{REFERENCES}

BHALERAO, G.D., 1937. Studies on the helmin ths of India. Trematoda IV. J. Helminth., 15:97-124.

GUPTA, S.P. \& VERMA, S.L., 1977. On some trematode parasites of fresh-water fishes. Riv. Parassit., $37: 171-182$.

KAKAJI, V.L., 1969. Studies on helminth parasites of Indian fishes. Indian J. Helminth., 21:49-80.

LEWIS, F.J., 1935. The trematode genus Phyllodistomum Braun. Trans. Amer. Micr. Soc., 54 :103117.

ODHNER, T., 1902. Mitteilung zur Kenntnis der Distomen. Zbl. Bakt., 31 :58-69.

ODHNER, T., 1911. Nordostafrikanische Trematoden, Grösstenteils vom weissen Nil (von der Schwedischen Zoologischen Expedition gesammelt). Res. Swed. Zool. Exp. Egypt \& White Nile, 4 $: 1-66$. 